\title{
AKTIVITAS ANTIBAKTERI DAN ANALISIS KLT-BIOAUTOGRAFI DARI FRAKSI BIJI KOPI ROBUSTA (Coffea canephora Pierre ex A. Froehner)
}

\author{
Wazhifa Andarini Paputungan"), Widya Astuty Lolo ${ }^{1)}$, Jainer Pasca Siampa ${ }^{1)}$ \\ ${ }^{1)}$ Program Studi Farmasi FMIPA UNSRAT Manado, 95115
}

\begin{abstract}
Coffee is a plant that contains compounds such as flavonoids, which have antibacterial activity. The purpose of this study was to determine the fraction of the ethanol extract of robusta coffee beans whether it has an antibacterial effect and know the class of compounds identified after TLC-Bioautography. The extraction method used was maceration with $96 \%$ ethanol and fractionation using liquid-liquid method with methanol, n-hexane, and ethyl acetate. Antibacterial testing using the agar diffudion method with concentration of 10\%, 20\%, 30\% respectively. The results of study of 30\% methanol fraction for Staphylococcus aureus bacteria have a 12,58 $\mathrm{mm}$ inhibition zone and Escherichia coli bacteria 11,60 in the strong category. The largest fraction of the inhibition zone is the 30\% methanol fraction of robusta coffee beans was carried out by TLC-Bioautography test using the mobile phase of chloroform : n-hexane (1:2). Tests for antibacterial activity with contact bioautography methods resulted in spotting on the chromatogram, which produces a inhibitory zone. The characteristics of the spots were carried out with the appearance of $\mathrm{AlCl}_{3}$ and dragendorf patches which were suspected to be flavonoids and alkaloids.
\end{abstract}

Keywords : Fraction, Antibacterial, Coffea canephora Pierre ex A. Froehner, TLC Bioautography.

\begin{abstract}
ABSTRAK
Kopi adalah tanaman yang mengandung senyawa antara lain flavonoid yang mempunyai aktivitas antibakteri. Tujuan dari penelitian ini adalah untuk mengetahui fraksi dari ekstrak etanol biji kopi robusta apakah memiliki efek antibakteri dan mengetahui golongan senyawa yang teridentifikasi memiliki aktivitas antibakteri setelah dilakukan pengujian KLT-Bioautografi. Metode ekstraksi yang digunakan adalah maserasi dengan pelarut etanol 96\% dan dilakukan fraksinasi dengan metode cair-cair dengan pelarut metanol, n-heksan, dan etil asetat. Pada pengujian antibakteri menggunakan metode difusi agar dengan konsentrasi 10\%, 20\%, 30\%. Hasil penelitian fraksi metanol konsentrasi $30 \%$ untuk bakteri Staphylococcus aureus memiliki zona hambat 12,58 $\mathrm{mm}$ dan bakteri Escherichia coli 11,60 mm dengan kategori kuat. Fraksi yang paling besar zona hambatnya yaitu fraksi metanol konsentrasi 30\% dilakukan pengujian KLT-Bioautografi menggunakan Bioautografi kontak. Aktivitas antibakteri terhadap fraksi metanol biji kopi robusta dilakukan dengan uji KLT-Bioautografi menggunakan fase gerak kloroform : n-heksan (1:2). Pengujian aktivitas antibakteri dengan metode bioautografi kontak hasil yang diperoleh terdapat bercak pada kromatogram yang menghasilkan zona hambat. Karakteristik bercak dilakukan dengan penampak bercak $\mathrm{AlCl}_{3}$ dan dragendorf diduga bercak tersebut adalah flavonoid dan alkaloid.
\end{abstract}

Kata kunci : Fraksi, Antibakteri, Coffea canephora Pierre ex A. Froehner, KLT-Bioautografi. 


\section{PENDAHULUAN}

Kopi merupakan salah satu tanaman yang mengandung senyawa antioksidan antaralain polifenol, flavonoid, proantisianidin kumarin, asam klorogenat, trigonelin dan tokoferol. Dalam ekstrak biji kopi robusta terdapat beberapa senyawa yang mempunyai aktivitas antibakteri. Dari penelitian yang telah dilakukan oleh Lubis (2018) pertumbuhan Staphylococcus aureus akan terhambat setelah pemberian $10 \%$ ekstrak biji kopi robusta.

Kopi berpotensi ditarik bahan aktifnya menggunakan metode ekstraksi. Ekstraksi adalah pemisahan bagian aktif sebagai obat dari jaringan tumbuhan menggunakan pelarut yang sesuai dengan prosedur yang telah ditetapkan (Rahmadani, 2015)

Bioautografi, berasal dari kata bio yang berarti makhluk hidup dan autografi berarti melakukan aktivitas sendiri. Bioautografi adalah suatu metode pendeteksian untuk menemukan suatu senyawa antimikroba yang belum teridentifikasi dengan cara melokalisir aktivitas antimikroba tersebut pada suatu kromatogram. Metode ini memanfaatkan pengertian kromatografi lapis tipis (Lukman, 2016).

Hasil penelitian yang telah dilakukan oleh Tanauma (2016) tentang aktivitas antibakteri ekstrak biji kopi robusta terhadap bakteri Escherichia coli menyatakan bahwa ekstrak biji kopi kopi robusta dapat menghambat bakteri Escherichia coli. Penelitian yang telah dilakukan oleh Tanauma pada tahun 2016 aktivitas antibakteri ekstrak biji kopi robusta dengan konsentrasi $10 \%$ menghasilkan diameter zona hambat sebesar $22,5 \mathrm{~mm}$.

\section{METODOLOGI PENELITIAN Waktu dan Tempat Penelitian}

Penelitian ini dilaksanakan pada bulan Februari sampai April 2019, di Laboratorium Biologi Dasar Jurusan Biologi, Laboratorium Farmasi Lanjutan Program Studi Farmasi Universitas Sam Ratulangi. Lokasi pengambilan sampel di Desa Modayag Kecamatan Modayag Kabupaten Bolaang Mongondow Timur.

\section{Bentuk Penelitian}

Penelitian ini dilakukan dengan menggunakan metode eksperimental laboratorium yaitu melalui uji aktivitas antibakteri dan analisis KLT-Bioautografi.

\section{Alat dan Bahan}

a. Alat

Alat yang digunakan dalam penelitian ini ialah pisau, masker, sarung tangan, jas lab, erlenmeyer (Pyrex), timbangan analitik (Kern), gelas ukur (Pyrex), gelas kimia (Pyrex), cawan petri (Normax), corong pisah, autoklaf $(A L P)$, pinset, spatula, pembakar spritus, pipet tetes, jarum ose, $\mathrm{L}$ glass, batang pengaduk, laminar air flow $(N$ Biotek), rak tabung reaksi, tabung reaksi (Pyrex), lemari pendingin (Samsung), inkubator (Ecocell), cakram (Paper disc), mikropipet (Ecopipette), vial, pot salep, jangka sorong.

b. Bahan

Bahan yang digunakan dalam penelitian ini ialah sampel biji kopi robusta, etanol 
96\%, metanol, n-heksan, etil asetat, larutan $\mathrm{H}_{2} \mathrm{SO}_{4} 1 \%, \mathrm{BaCl}_{2} 1,75 \%, \mathrm{NaCl} 0,9 \%$, aquades, biakan mikroba Escherichia coli ATCC 25922 (gram negatif), Staphylococcus aureus ATCC 25923 (gram positif), Nutrien Agar (NA), Kloramfenikol paper disc, alkohol, wadah maserasi, label, tissue, lempeng silica gel, kertas saring, alumunium foil.

\section{Prosedur Penelitian}

\section{Ekstraksi}

Sampel ditimbang sebanyak $600 \mathrm{~g}$, diekstraksi secara maserasi menggunakan etanol 96\% sebanyak $1800 \mathrm{ml}$ hingga terendam seluruhnya. Wadah maserasi ditutup dengan aluminium foil dan disimpan selama 24 jam ditempat yang terlindung dari sinar matahari langsung sambil sesekali diaduk. Maserasi dilakukan selama 3×24 jam. Sampel yang telah direndam disaring dengan menggunakan kertas saring menghasilkan filtrat 1 dan debris 1 . Selanjutnya proses remaserasi selama 2 hari dengan merendam debris 1 dengan pelarut etanol 96\%. Setelah 2 hari sampel tersebut disaring menggunakan kertas saring menghasilkan filtrat 2 dan debris 2 . Filtrat 1 dan 2 dicampurkan menjadi satu kemudian disaring, lalu hasil penyaringan kemudian diuapkan dengan oven hingga diperoleh ekstrak kental kopi robusta. Ditimbang menggunakan timbangan analitik diperoleh ekstrak sebanyak 63,63 g. Ekstrak kental yang sudah di timbang disimpan dalam wadah gelas tertutup untuk digunakan dalam pengujian.

\section{Fraksinasi}

Fraksinasi dilakukan dengan metode cair-cair, Ekstrak kental yang diperoleh selanjutnya difraksinasi dengan menggunakan 3 pelarut dengan tingkat kepolaran yang berbeda-beda, yaitu nheksan, etil asetat, dan metanol. Proses fraksinasi dilakukan dengan melarutkan sampel sebanyak $10 \mathrm{~g}$ ekstrak kental dengan metanol sebanyak $100 \mathrm{ml}$ di aduk hingga homogen dan ditambahkan pelarut n-heksan sebanyak $100 \mathrm{ml}$ selanjutnya dimasukkan ke dalam corong pisah dikocok hingga terpisah 2 lapisan, lapisan atas merupakan fase $\mathrm{n}$ heksan dan lapisan bawah merupakan fase metanol masing-masing lapisan ditampung pada wadah yang berbeda. Cara yang sama dilakukan untuk pelarut etil asetat.

\section{Sterilisasi dan Pembuatan Media Sterilisasi Alat}

Alat-alat gelas yang digunakan dalam penelitian aktivitas antibakteri ini disterilkan terlebih dahulu dengan menggunakan autoklaf pada suhu $121^{\circ} \mathrm{C}$ selama 15 menit. Sedangkan pinset, jarum ose dan L glass dipijarkan diatas api bunsen.

\section{Pembuatan Media Nutrient Agar}

Nutrien Agar sebanyak 10,08 g ditimbang dan ditambahkan dengan aquadest sampai $360 \mathrm{~mL}$ dan dilarutkan hingga homogen. Media yang telah homogen kemudian disterilkan dengan menggunakan autoklaf pada suhu $121^{\circ} \mathrm{C}$ selama 15 menit, dan dibiarkan sampai media cukup dingin. Selanjutnya media nutrien Agar yang masih cair dituang ke dalam 18 cawan petri masing-masing sebanyak $20 \mathrm{~mL}$. dan dibiarkan hingga memadat. 


\section{Pembuatan Media Agar Miring}

Pembuatan agar miring dilakukan dengan memasukkan $10 \mathrm{~mL}$ media yang telah disterilkan dalam tabung reaksi kemudian disumbat dengan kapas steril dan dimiringkan sekitar $45^{\circ} \mathrm{C}$. Didiamkan hingga memadat pada suhu ruangan. Media agar miring digunakan sebagai peremajaan bakteri.

\section{Pengujian Aktivitas Antibakteri}

\section{Pembuatan Larutan standar Mc Farland}

\section{0,5}

Larutan $\mathrm{H}_{2} \mathrm{~S} 04 \quad 1 \%$ sebanyak 9,95 $\mathrm{mL}$ dicampurkan dengan larutan $\mathrm{BaCl}_{2}$. $2 \mathrm{H}_{2} \mathrm{O} \quad 1,75 \%$ sebanyak $0,05 \% \mathrm{~mL}$ dalam Erlenmeyer. Kemudian dikocok sampai terbentuk larutan yang keruh sebagai standar kekeruhan suspense mikroba uji.

\section{Pembuatan Suspensi Bakteri Uji}

Bakteri uji yaitu Staphylococcus aureus dan Escherichia coli yang telah diinokulasi diambil kurang lebih 1 ose kemudian disuspensikan ke dalam tabung yang berisi $10 \mathrm{~mL}$ larutan $\mathrm{NaCL} 0,9 \%$. Selanjutnya dibandingkan dengan standar kekeruhan larutan Mc Farland 0,5.

\section{Kontrol Positif dan Kontrol Negatif}

Kontrol Positif untuk pengujian aktivitas antibakteri ini menggunakan Kloramfenikol paper disc dan untuk kontrol negatif menggunakan akuades.

\section{Pembuatan Larutan Uji}

Dibuat larutan stok untuk konsentrasi $100 \%$ dengan cara menimbang $1 \mathrm{~g}$ fraksi metanol, fraksi etil asetat, fraksi n-heksan, masing-masing dilarutkan dengan aquadest hingga $1 \mathrm{ml}$. Larutan uji fraksi metanol, etil asetat, n-heksan 10\%, 20\%, 30\%, dibuat dengan cara mengambil masing-masing sebanyak $0,1 \mathrm{~mL}, 0,2 \mathrm{~mL}$, dan $0,3 \mathrm{~mL}$ untuk setiap konsentrasi dan dicukupkan dengan aquadest hingga $1 \mathrm{~mL}$.

\section{Pengujian Aktivitas Antibakteri}

\begin{tabular}{llr}
\multicolumn{2}{c}{ Pada penelitian ini digunakan } \\
metode difusi agar. Aktivitas
\end{tabular}
penghambatanya di uji terhadap Staphylococcus aureus dan Escherichia coli yang digunakan sebagai mikroorganisme uji. Digunakan kertas cakram yang berukuran 6 mm untuk pengujian aktivitas antibakteri. Media NA dituang masing-masing sebanyak $20 \mathrm{~mL}$ kedalam 18 cawan petri hingga memadat. Pada permukaan media yang sudah memadat dimasukkan suspensi bakteri uji. Sampel yang telah ditentukan konsentrasinya ditotolkan pada masingmasing cakram dengan menggunakan mikropipet sebanyak $50 \mu \mathrm{L}$. Masing-masing cakram diberi label sesuai dengan komponen pengujian. Kertas cakram yang telah ditotolkan larutan uji terdiri dari kontrol positif, kontrol negatif, dan yang mengandung larutan uji diletakkan ke dalam cawan petri dan disesuaikan jaraknya dengan pinset lalu diinkubasi selama 24 jam.

\section{Pengamatan dan Pengukuran Zona Bening}

Pengamatan dilakukan setelah $1 \times 24$ jam dalam inkubasi. Daerah pada sekitaran cakram menunjukkan kepekaan bakteri terhadap antibiotik atau larutan uji yang digunakan. Diameter zona bening diukur dalam satuan milimeter (mm) menggunkan 
jangka sorong dengan cara diukur diameter zona bening horizontal ditambahkan dengan diameter zona bening vertikal lalu dibagi dua.

\section{Pengujian Fraksi Teraktif dengan Metode KLT-Bioautografi}

Fraksi yang memiliki zona bening yang paling besar dilanjutkan pada pemantauan KLT. Hasil pemantauan KLT di uji aktivitas antibakterinya dengan metode KLT-Bioautografi.

\section{Persiapan Plat KLT}

Pemisahan senyawa dari fraksi teraktif dilakukan dengan menggunakan plat silika sebagai fase diam dengan ukuran $1 \mathrm{x}$ $10 \mathrm{~cm}$. Selanjutnya diberi tanda garis pada tepi atas dan bawah plat dengan jarak $1 \mathrm{~cm}$ untuk menunjukkan posisi awal totolan dan tepi atas sebagai tanda batas dari proses elusi. Selanjutnya plat diaktifkan dengan cara dipanaskan pada suhu $105^{\circ} \mathrm{C}$ selama 10 menit untuk menghilangkan kadar air yang terdapat pada plat KLT.

\section{Persiapan Fase Gerak (Eluen)}

Sebelum dilakukan pengelusian, eluen yang digunakan yaitu fraksinat metanol menggunakan eluen kloroform dan n-heksan dengan perbandingan (1:2) eluen yang berada di dalam bejana dijenuhkan terlebih dahulu, setiap campuran fase gerak dimasukkan dalam chamber lalu ditutup rapat dan dilakukan penjenuhan dengan menggunakan kertas saring selama 10 menit. Penjenuhan ini dilakukan untuk menyamakan tekanan uap pada seluruh bejana.

\section{Penotolan Sampel Fraksi}

Fraksi metanol dengan konsentrasi $30 \%$ ditotolkan pada tiga lempeng yang berbeda dengan jarak $1 \mathrm{~cm}$ dari tepi bawah plat dengan menggunakan pipa kapiler. Kemudian dikeringkan dengan cara dianginanginkan. Lempeng pertama diamati dengan lampu UV 254 nm dan lampu UV 366 nm. Lempeng kedua disemprotkan reagen Aluminium Klorida $\mathrm{AlCl}_{3}$ untuk melihat senyawa flavonoid dan dragendorf untuk melihat senyawa alkaloid. lempeng ke tiga digunakan untuk uji bioautografi.

\section{Uji Bioautografi}

Nutrien Agar sebanyak 0,56 g ditimbang dan ditambahkan dengan aquadest sampai $20 \mathrm{~mL}$ dan dilarutkan hingga homogen. Media yang telah homogen kemudian disterilkan dengan menggunakan autoklaf pada suhu $121^{\circ} \mathrm{C}$ selama 15 menit, dan dibiarkan sampai media cukup dingin. Selanjutnya media nutrien Agar yang masih cair dituang ke dalam cawan petri masing-masing sebanyak $20 \mathrm{~mL}$. dan dibiarkan hingga memadat. Kromatogram hasil pemisahan senyawa secara KLT diletakkan diatas medium yang memadat. Didiamkan selama 30 menit dilemari pendingin, lempeng kromatogram diangkat dan dikeluarkan dari medium. Selanjutnya diinkubasi selama 1 x 24 jam pada suhu $37^{\circ} \mathrm{C}$.

\section{HASIL DAN PEMBAHASAN \\ Ekstraksi dan Fraksinasi}

$$
\text { Sampel biji kopi robusta Coffea }
$$
canephora diambil di Desa Modayag Kecamatan Modayag Bolaang Mongondow Timur dilakukan sortasi basah untuk 
memisahkan kotoran-kotoran atau bahan asing lainnya dari tumbuhan sebelum pencucian dengan cara membuang bagianbagian yang tidak perlu sebelum pengeringan. Selanjutnya dicuci di bawah air mengalir untuk menghilangkan tanah dan pengotor lainnya yang melekat pada biji kopi kemudian ditiriskan. Dilakukan sortasi kering untuk menghilangkan sisa-sisa kotoran yang masih ada dan tertinggal proses ini dilakukan secara manual. Sampel dikeringkan dengan menggunakan oven, pengeringan dengan oven dianggap lebih menguntungkan karena akan terjadi pengurangan kadar air dalam jumlah besar dalam waktu yang singkat (Wahyuni, 2014).

Maserat yang diperoleh dari proses maserasi selanjutnya dipekatkan menggunakan oven pada suhu $40^{\circ} \mathrm{C}$ untuk memperoleh ekstrak kental selanjutnya digunakan dalam fraksinasi. Ekstrak kental yang diperoleh selanjutnya difraksinasi dengan metode fraksinasi cair-cair. Metode fraksinasi ini menggunakan variasi pelarut yang memiliki kepolaran yang berbedabeda, yaitu metanol, etil asetat dan n-heksan, pemilihan ini di karena ketiga pelarut ini sudah mewakili kepolaran yang berbedabeda dimana metanol bersifat polar, etil aseat bersifat semi polar dan n-heksan bersifat non polar sehingga senyawasenyawa yang memiliki kepolaran berbedah dapat terpisah kedalam pelarut yang sesuai.

\section{Pengujian Aktivitas Antibakteri}

Pengujian aktivitas antibakteri fraksi metanol, fraksi etil asetat dan fraksi nheksan pada bakteri uji Staphylococcus aureus untuk mewakili bakteri golongan
Gram positif dan Escherichia coli untuk mewakili bakteri golongan Gram negatif.

Pengujian aktivitas antibakteri menggunakan metode difusi agar (disc diffusion Kriby and Bauer). Metode ini dilakukan dengan menggunakan kertas cakram yang berisi senyawa antibakteri, kemudian diletakkan pada media padat yang telah diinokulasi bakteri. Senyawa antibakteri akan berdifusi ke dalam media padat yang diinokulasi bakteri dan menghambat pertumbuhan bakteri yang ditandai dengan terbentuknya daerah bening di sekeliling kertas cakram (Brooks et al., 2005). Metode ini dipilih karena pengerjaan yang sederhana, mudah dikerjakan, ketelitian, tidak memerlukan peralatan yang khusus, metode serbaguna bagi semua bakteri patogen yang tumbuh cepat dan sering digunakan dalam uji kepekaan antibiotik dalam program pengendalian mutu.

Tabel 1. Hasil rata-rata diameter zona hambat terhadap bakteri uji Staphylococcus aureus .

\begin{tabular}{llll}
\hline \multirow{4}{*}{ Fraksi } & \multicolumn{3}{l}{$\begin{array}{l}\text { Rata-rata diameter zona bening }(\mathrm{mm}) \\
\text { pada setiap konsentrasi }\end{array}$} \\
\cline { 2 - 4 } & $10 \%$ & $20 \%$ & $30 \%$ \\
\hline $\begin{array}{l}\text { Fraksi } \\
\text { metanol }\end{array}$ & 9,16 & 11,33 & 12,58 \\
\hline $\begin{array}{l}\text { Fraksi etil } \\
\text { asetat }\end{array}$ & 8,16 & 10,00 & 11,00 \\
\hline $\begin{array}{l}\text { Fraksi n- } \\
\text { heksan }\end{array}$ & 8,00 & 9,66 & 10,75 \\
\hline $\begin{array}{l}\text { Kontrol } \\
\text { positif }\end{array}$ & 15,33 & 11,66 & 13,16 \\
\hline $\begin{array}{l}\text { Kontrol } \\
\text { negatif }\end{array}$ & 0 & 0 & 0 \\
\hline
\end{tabular}


Tabel 2. Hasil rata-rata diameter zona hambat terhadap bakteri uji Escherichia coli

\begin{tabular}{lccc}
\multirow{2}{*}{ Fraksi } & \multicolumn{3}{c}{$\begin{array}{l}\text { Rata-rata diameter zona bening }(\mathrm{mm}) \\
\text { pada setiap konsentrasi }\end{array}$} \\
\cline { 2 - 4 } & $10 \%$ & $20 \%$ & $30 \%$ \\
\hline $\begin{array}{l}\text { Fraksi } \\
\text { methanol }\end{array}$ & 9,33 & 10,33 & 11,60 \\
\hline $\begin{array}{l}\text { Fraksi etil } \\
\text { asetat }\end{array}$ & 8,33 & 9,25 & 9,66 \\
\hline $\begin{array}{l}\text { Fraksi n- } \\
\text { heksan }\end{array}$ & 8,50 & 9,00 & 9,16 \\
\hline $\begin{array}{l}\text { Kontrol } \\
\text { positif }\end{array}$ & 19,41 & 19,33 & 19,66 \\
\hline $\begin{array}{l}\text { Kontrol } \\
\text { negatif }\end{array}$ & 0 & 0 & 0 \\
\hline
\end{tabular}

Hasil yang diperoleh dari fraksi metanol, n-heksan dan etil asetat menunjukan diameter zona hambat yang lebih besar pada konsentrasi 30\% terhadap bakteri Staphylococcus aureus hal ini karena menurut Pelczar (1998), menyatakan bahwa bakteri Gram positif memiliki struktur dinding sel yang lebih banyak peptidoglikan, sedikit lipid dan tidak mempunyai lapisan lipopolisakrida sehingga senyawa antibakteri yang bersifar hidrofilik maupun hidrofobik dapat dengan mudah melewati dinding sel. Kerusakan sel bakteri yang terjadi pada dinding, membran dan bagian internal sel akan menyebabkan bakteri tidak dapat menahan tekanan osmotik tinggi dari dalam sel sehingga mengakibatkan sel menjadi lisis. Sedangkan struktur dinding sel bakteri Gram negatif lebih kompleks dan berlapis tiga, yaitu lapisan luar berupa lipoprotein, lapisan tengah berupa petidoglikan dan lapisan dalam lipopolisakrida (Placzar dan Chan, 1986). Struktur dinding sel yang relatif kompleks ini menyebabkan antibakteri lebih sukar masuk kedalam sel.
Kontrol positif menunjukkan perbedaan yang nyata, Karena menghasilkan aktivitas antibakteri yang paling besar terhadap bakteri uji dibandingkan dengan kontrol negatif, ekstrak maupun fraksi bahan uji. Untuk pengujian ini antibiotik yang digunakan yaitu kloramfenikol. Kontrol positif berfungsi sebagai pembanding antara antibakteri yang sudah terstandarisasi dengan larutan fraksi dalam hal ini Coffea canephora. Hasil penelitian ini menunjukkan diameter zona hambat kloramfenikol yang terbentuk, lebih besar pada bakteri gram negatif Escherichia coli dibandingkan gram positif Staphylococcus aureus.

Hasil yang diperoleh menunjukkan diameter zona hambat bakteri Staphylococcus aureus dan Escherichia coli yang terbentuk pada konsentrasi fraksi $30 \%$ lebih besar dibandingkan dengan konsentrasi fraksi $10 \%$ dan $20 \%$. Hal ini membuktikan bahwa semakin tinggi konsentrasi larutan uji, maka semakin besar pada diameter zona hambat yang terbentuk.

Hasil uji statistik menggunakan anova two way untuk bakteri Staphylococcus aureus dan Escherichia coli. Dari data tabel ANOVA ( Test Of BetweenSubjects Effects) Menunjukkan bahwa setiap pelarut memiliki kemampuan yang berbeda terhadap daya hambat bakteri. Hal ini menunjukkan perbedaan bermakna dengan nilai $0.00(\mathrm{p}<0,05)$. Hasil yang diperoleh fraksi dengan penggunaan pelarut metanol adalah yang paling baik. 


\section{Pengujian Fraksi Teraktif Dengan Metode KLT-Bioautografi}

KLT-Bioautografi merupakan

pengujian lanjutan yang berfungsi untuk mengetahui komponen kimia apa yang memberikan aktivitas antibakteri dari fraksi metanol biji kopi robusta dengan fraksi yang terpilih yaitu metanol 30\%. Eluen yang digunakan adalah kloroform dan n-heksan dengan perbandingan (1:2), Pemilihan eluen sebaiknya dimulai dari pelarut organik yang non polar dan peningkatan kepolaran dengan pelarut yang lebih polar lainnya (Gritter, 1991).

Metode yang digunakan dalam KLTBioautografi ialah metode kontak yaitu dengan menempelkan lempeng KLT diatas medium agar yang telah diinokulasikan dengan bakteri uji. Terdapat zona bening yang terbentuk pada titik bawah yang menjadi tempat totolan ekstrak namun tidak terdapat zona bening pada bagian-bagian spot yang naik hal ini kemungkinan terjadi karena kekurangan dari metode kontak yaitu penyerapan oleh permukaan agar dan kesulitan untuk mendapatkan kontak yang optimal antara agar dan kromatogram sehingga matriks lempeng melekat dan tertinggal pada agar ketika lempeng kromatogram di angkat kembali. Beberapa senyawa dapat berikatan dengan matriks lempeng kromatogram terutama matriks berbasis silica sehingga beberapa senyawa tidak perna berdifusi ke dalam agar (Pakata, 2013).

Identifikasi komponen kimia dilakukan untuk mengetahui golongan senyawa yang terkandung dalam ekstrak menggunakan lempeng KLT yang telah disemprotkan dengan pereaksi. Pereaksi
$\mathrm{AlCl}_{3}$ menunjukkan senyawa flavonoid jika noda yang tampak berwarna kuning dan pereaksi dragendorf menunjukkan senyawa alkaloid jika noda tampak berwarna orange. Berdasarkan warna yang ditunjukkan pada pereaksi maka ekstrak diduga mengandung senyawa flavonoid dan alkaloid. Beberapa penelitian sebelumnya telah menunjukkan kandungan senyawa yang terdapat pada biji kopi robusta diantaranya mengandung senyawa flavonoid dan alkaloid.

\section{KESIMPULAN}

Berdasarkan hasil penelitian dapat disimpulkan bahwa :

1. Fraksi biji kopi robusta memiliki aktivitas antibakteri terhadap Staphylococcus aureus dan Escherichia coli dengan kategori kuat.

2. Komponen kimia aktif yang memberikan aktivitas antibakteri secara KLT-bioautografi pada fraksi terpilih yaitu methanol diduga adalah golongan flavonoid dan alkaloid.

\section{SARAN}

Perlu dilakukan penelitian lagi untuk mengidentifikasi golongan senyawa lain yang ada pada biji kopi robusta Coffea canephora dengan menggunakan metode KLT-Bioautografi langsung.

\section{DAFTAR PUSTAKA}

Brooks, G. L., J.S. Butel. S.A Morse. 2005. Mikrobiologi Kedokteran Ed. 23. Jakarta : Salemba Medika.

Gritter, R. 1991. Pengantar Kromatografi edisi 2. Alih bahasa oleh Kosasih Padmawinata, Bandung: ITB 
Lubis, M. R. R. 2018. Pengaruh Konsentrasi Ekstrak Biji Kopi Robusta (Coffea canephora) Terhadap PH Saliva dan Pertumbuhan Bakteri Staphylococcus aureus (IN VITRO) (ATCC 29213). [Skripsi]. Medan : Universitas Sumatera Utara

Lukman, A. 2016. Uji Aktivitas Antibakteri Ekstrak Biji Kopi Robusta (Coffea canephora) terhadap $\mathrm{PH}$ saliva dan Pertumbuhan Bakteri Staphylococcus aureus (ATCC 29213) (in vitro). [Skripsi]. Medan : Universitas Sumatera Utara.

Pakata, iin. 2013. Uji Aktivitas Antiikroba Dari Ekstrak dan Fraksi Aktif Buah Cabai Katokkon (Capsium annum L. var. chinensis) Secara KLTBioautografi. Makassar. Universitas Hasanuddin.

Pelczar, M. J., Chan, E. C. S., 1986. Dasardasar Mikrobiologi. Terjemahan Hadioetomo, R.S. Imas, T.S.S., Tjitrosomo. Jakarta : UI Press.

Rahmadani, Fitri.2015. Uji Aktivitas Antibakteri dari Ekstrak Etanol 96\% Kulit Batang Kayu Jawa (Lannea coromandelica) Terhadap Bakteri Staphylococcus aureus, Escherichia coli, Helicobacter pylori, Pseudomonas aeruginosa. [Skripsi]. Jakarta : Fakultas Kedokteran dan Ilmu Kesehatan UIN Syarif Hidayatullah.

Tanauma, H. 2016. Aktivitas Antibakteri Ekstrak Biji Kopi Robusta (Coffea canephora) Terhadap Bakteri Escherichia coli. Jurnal Ilmiah Farmasi. 5(4) : 244-251.

Wahyuni, R. 2014. Pengaruh Cara Pengeringan Dengan Oven, Kering angin dan Cahaya Matahari Langsung Terhadap Mutu Simplisia Herba Sambiloto. Jurnal Farmasi Higea. 6 (2) : 127 - 132. 